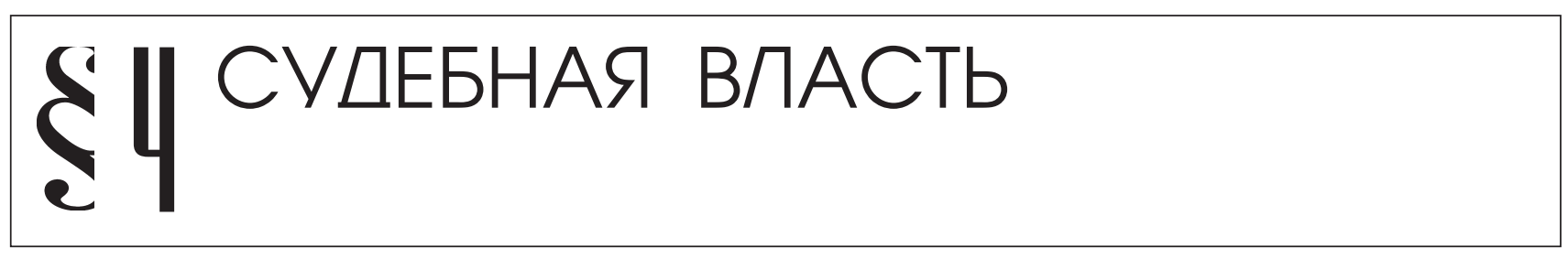

Мильчакова O.B.

\title{
ПРЕДЕЛЫ ВМЕШАТЕЛЬСТВА ЕВРОПЕЙСКОГО СУДА ПО ПРАВАМ ЧЕЛОВЕКА В ДЕЯТЕЛЬНОСТЬ КОНСТИТУЦИОННОГО СУДА БОСНИИ И ГЕРЦЕГОВИНЫ
}

\begin{abstract}
Аннотация: Статья посвящена особенностям взаимоотношений Европейского суда по правам человека (ЕСПЧ) с начиональными конституционными судами. С иелью выявления специфики этих отношений автор обращается $\kappa$ Боснии и Гериеговине (БиГ), третья часть состава Конституиионного суда в которой назначается непосредственно Председателем ЕСПЧ.На основе анализа зарубежного законодательства, прецедентов ЕСПЧ и Конституционного суда БиГ, а также конкретных исторических фактов и политических событий отражены различные аспекты взаимоотнотений указанных судов, в том числе связанные с проблемами исполнения решений ЕСПЧ. При проведении исследования указанной тематики автором в основном используется формально-юридический метод, а также исторический метод. Результаты исследования приводят автора к заключению о том, что фактически для ЕСПЧ не существует пределов для вмешательства в деятельность Конституционного суда БиГ, а последний представляется более независимым от национальных органов, чем от ЕСПЧ. При этом другие государства, международные и надначиональные органы и организации нередко используют как политические, так и финансовые рычаги давления на БиГ в целях понуждения ее к исполнению решений ЕСПЧ, вплоть до проведения конституиионной реформыл.
\end{abstract}

Abstract: The article concerns the peculiarities of relationship between the European Court of Human Rights (ECHR) and national constitutional courts. In order to identify the specifics of this relationship, the author turns to Bosnia and Herzegovina (BiH), the third part of the Constitutional Court of which is appointed directly by the Chairman of the ECHR. Based on the analysis of foreign law, the case law of the ECHR and the Constitutional Court of BiH, as well as specific historical facts and political developments, the article reflects different aspects of the relationship of these courts, including problems related to the implementation of the ECHR decisions. In conducting the research of the specified subjects, the author mainly used legalistic and historical methods. The results of study led the author to the conclusion that there are virtually no limits to ECHR intervention in the activities of the Constitutional Court of BiH; the latter seems to be more independent from the national authorities than from the ECHR. However, other countries and international and supranational institutions and organizations often use both political and financial levers of influence on BiH in order to force it to fulfill ECHR decisions until the constitutional reform takes place.

Ключевые слова: Босния и Гериеговина, Страны бывщей Югославии, Конституционный суд, Конституция, Конституционный контроль, Европейский суд, ЕСПЧ, Европейская конвенция, Конвенционный контроль, Доступ к суду Keywords: Bosnia and Herzegovina, the Former Yugoslavia, the Constitutional Court, the Constitution, the Constitutional control, the European Court, the ECHR, the European Convention, Conventional control, access to the court.

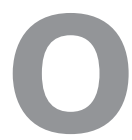
собенности организации Конституционного суда Боснии и Герцеговины во многом предопределены историческими и политическими обстоятельствами, сопутствующими процессу становления современного государства в Боснии и Герцеговине (БиГ).

Впервые Конституционный суд в БиГ был создан 15 февраля 1964 г., одновременно с конституционны- ми судами в других пяти республиках (Македония, Сербия, Словения, Хорватия, Черногория), которые на тот момент, наряду с БиГ, входили в состав Социалистической Федеративной Республики Югославии (СФРЮ). Союзной Конституцией 1963 г. были учреждены конституционные суды на уровне федерации, ее республик-членов и немного позднее - в автономных краях Косове и Воеводине. Деятельность 
DOI: $10.7256 / 1811-9018.2014 .2 .10872$

При цитировании этой статьи сноска на доі обязательна

\section{Право и политика $2(170) \cdot 2014$}

существовавших тогда конституционных судов во многом носила формальный характер, поскольку социалистическая система не позволяла им полноценно реализовывать возложенные на них задачи.

В конце прошлого века в Восточной Европе пали коммунистические режимы, а единое союзное государство СФРЮ распалось, в том числе в результате обострения межнациональных и межреспубликанских отношений после смерти в 1980 г. его Президента И. Броза Тито (1892 - 1980). БиГ объявила о своей независимости в 1992 г., вслед за Словенией и Хорватией.

Сразу после распада СФРЮ, пожалуй, в БиГ намного более сильнее, чем в других республиках бывшей СФРЮ, были осложнены межэтнические отношения, а оформление самостоятельного государства здесь происходило с более серьезными трудностями. На момент выхода БиГ из состава СФРЮ в ней проживали преимущественно боснийцы (44\%, славяне, принявшие ислам), сербы (31\%, по большей части православные) и хорваты (17\%, в основном католики). Результаты референдума о независимости, проведенного 29.02.1992, были отвергнуты лидерами боснийских сербов, которые бойкотировали референдум и создали свою собственную республику - Республику Сербскую. После провозглашения независимости вспыхнул вооруженный конфликт, в котором боснийские сербы получили поддержку от Правительства Сербии, возглавляемого С. Милошевичем (1941 - 2006), и Югославской Народной Армии. Вскоре боевые действия распространились на всю территорию государства и начались первые этнические чистки против боснийского населения.

В урегулировании конфликтов в БиГ активное участие в 1991-1994 гг. принимали Совещание по безопасности и сотрудничеству в Европе (СБСЕ), Европейский Союз (ЕС) и Организация Объединенных Наций (OOH). При этом, как отмечают профессор А. Абашидзе и А. Солнцев, на завершающем этапе переговорного процесса решающая роль отводилась Организации Североатлантического договора (НАТО), которая в процессе урегулирования боснийского кризиса использовала все методы - от ведения переговоров, предъявления ультиматумов до использования вооруженных сил ${ }^{1}$. Отрицательную роль также могло сыграть нежелание российского Президента Б. Ельцина (1931 - 2007) ссориться с Западом по данному вопросу.

В феврале 1994 г. переговоры между представителями конфликтующих сторон были сорваны и инициатива

\footnotetext{
${ }^{1}$ См.: Абашидзе А. Х., Солнцев А. М. Балкань - ахиллесова пята евро-атлантической безопасности. К 15-летию Дейтонских соглашений. // Обозреватель-Observer. 2010. № 8. С. 58.
}

урегулирования кризиса перешла к США. Было принято решение о создании контактной группы, возглавившей переговорный процесс, в которую вошли США, Германия, Великобритания и Россия. По ее инициативе была образована Федерация Боснии и Герцеговины, объединившая в своем составе территории, контролируемые боснийцами и хорватами. В соответствии с планом США Федерация Боснии и Герцеговины должна была вести переговоры с Республикой Сербской. В ноябре 1995 г. близ американского города Дейтон состоялись решающие переговоры, в результате которых были подписаны документы, вошедшие в историю как Дейтонские соглашения по Боснии и Герцеговине. Они включают 20 документов, 19 из которых являются приложениями к документу обобщающего характера «Общее рамочное соглашение о мире в Боснии и Герцеговине» ${ }^{2}$. Приложение 4 к указанному документу содержит текст Конституции БиГ, вступившей в силу 14 декабря 1995 г. и действующей по настоящее время. Таким образом, нельзя сказать, что Конституция БиГ принята на основе общепринятых демократических процедур, скорее, она была навязана иностранными государствами, при этом ее текст, к слову сказать, был официально опубликован на английском (иностранном для страны) языке, а не на ее официальных языках (боснийский, сербский, хорватский).

Конституция называет государствообразующими народами боснийцев, хорватов и сербов ${ }^{3}$, несмотря на проживание в стране лиц и других национальностей (цыгане, евреи, албанцы, словенцы и др.). В качестве коллективного президента государства выступает Президиум Боснии и Герцеговины, в состав которого входят один босниец, один хорват, избираемые прямыми выборами на территории Федерации, а также один серб, избираемый прямыми выборами на территории Республики Сербской.

Территориально страна разделена на два энтитета (Федерация Боснии и Герцеговины, где преимущественно проживают боснийцы и хорваты, и Республика Сербская, население которой составляют в основном боснийские сербы) и округ Брчко с особым статусом ${ }^{4}$. Каждый энтитет имеет свои конституции,

\footnotetext{
${ }^{2}$ См.: Там же. С. 58-59.

${ }^{3}$ Устав Босне и Херцеговине. Сарајево. OHR, Office of the High Representative. $<$ http://www.ccbh.ba/srp/p_stream.php?kat=618>. (Последнее посещение: 25 января 2014 г.).

${ }^{4}$ Округ Брчко является особой автономной территориальной единицей в составе БиГ. Он был создан 8 марта 2000 г. на основе решения Арбитражного суда. Обязательный арбитраж спорной части границы между энтитетами в округе Брчко был предус-
} 
законодательство и органы власти, в том числе конституционные суды. Округ Брчко имеет собственные органы самоуправления (градоначальник, скупщина, правительство), а также устав и законодательство по вопросам переданной ему компетенции, которое не должно противоречить Конституции и законам БиГ. Функции органа конституционной юстиции возложены на Апелляционный суд округа Брчко.

Конституционному суду БиГ посвящена статья VI Конституции, где установлена его компетенция, определены правила формирования Суда, общие требования к производству по делам. При этом прямо не зафиксировано, является ли этот орган частью судебной системы (впрочем, в Конституции нет полноценных положений, отражающих структуру и функции судебной власти вообще). В стране не существует специального закона о Конституционном суде и основные элементы статуса последнего подробно регламентированы Правилами, принятыми им самим. Так, например, независимость Суда отражена не в Конституции, а в Правилах Конституционного суда Боснии и Герцеговины ${ }^{5}$ (далееПравила), ст. 2 которых гласит: Конституционный суд, по отношению к другим органам власти в БиГ, самостоятелен и независим; ни один орган в БиГ не может принимать законы, другие постановления и общие акты, касающиеся работы Конституционного суда и его роли, определенной Конституцией. Таким образом, в исследуемом государстве установлена европейская модель централизованного конституционного контроля, при которой соответствующие функции вверяются отдельному, независимому органу.

Согласно ч.ч. 3, 4 ст. VI Конституции Суд обеспечивает соблюдение Конституции, а его решения являются окончательными и обязательными. Компетенция Конституционного суда включает в себя: юрисдикцию по разрешению любого спора о Конституции, возника-

мотрен в ст. 5 приложения 2 Дейтонских соглашений. Каждый из энтитетов (Федерация Боснии и Герцеговины и Республика Сербская) назначили по одному арбитру в состав Арбитражного суда, а третьего арбитра - выбрали совместно. 5 марта 1999 г. Арбитражный суд вынес окончательное решение о том, что округ Брчко должен быть особой автономной единицей в составе БиГ, не входящей в состав ни одного из энтитетов. Международное вмешательство в решение вопроса о статусе района Брчко продиктовано не только стремлением разрешить территориальный спор между энтитетами, желающими получить равный доступ к бассейну реки Сава, в котором расположен округ, но и значительными запасами нефти, обнаруженными на территории округа.

${ }_{5}^{5}$ Правила Уставног суда Босне и Херцеговине. // Службени гласник Босне и Херцеговине, број 60/05, стр. 4905-4923. <http://www.ccbh. $\mathrm{ba} / \mathrm{srp} / \mathrm{p} \_$stream.php?kat $=618 \& \mathrm{pkat}=619>$. (Последнее посещение: 25 января 2014 г.). ющего между энтитетами или между БиГ и энтитетом или энтитетами либо между учреждениями БиГ (п. «а» ч. 3); апелляционную юрисдикцию в отношении вопросов, относящихся к Конституции, которые возникают в связи с решением любого другого суда в БиГ (п. «b» ч. 3); юрисдикцию в отношении вопросов, которые рассматриваются любым судом в БиГ и заключаются в установлении того, не противоречит ли закон, от действительности которого зависит решение суда, Конституции, европейской Конвенции о защите прав человека и основных свобод и протоколам к ней, или законам БиГ, либо того, что существует ли общая норма международного публичного права, имеющая отношение к решению суда, или какова сфера действия этой нормы (п. «с» ч. 3). Последнее, по своей сути, представляет так называемый «предварительный запрос суда».

К компетенции Суда также было отнесено рассмотрение дел по жалобам на нарушения прав человека, поданным в Палату по правам человека (орган, созданный на основании приложения 6 к Общему рамочному соглашению о мире в БиГ) до 31 декабря 2003 г. (то есть до даты окончания полномочий Палаты) и решение по которым не принято Комиссией по правам человека при Конституционном суде БиГ (орган, ставший правопреемником Палаты по правам человека по рассмотрению жалоб, поданных до 31.12.2003) по состоянию на 31.12.2006 (дата окончания срока ее полномочий). Данная компетенция была передана Суду на основании упомянутого приложения 6, а также ст. 7 Соглашения, заключенного между БиГ, Федерацией Боснии и Герцеговины и Республикой Сербской в январе 2007 г. ${ }^{6}$

Кроме того, поправкой I к Конституции, принятой в 2009 г. ${ }^{7}$, предусмотрено, что Конституционный суд обладает юрисдикцией принимать решения по любому спору, касающемуся защиты статуса и полномочий округа Брчко, который может появиться между округом Брчко и одним или обоими энтитетами, а также между БиГ и округом Брчко. При этом Суд рассматривает указанные споры на основе не только Конституции, но и решений Арбитражного суда.

С 2002 г. Босния и Герцеговина является членом Совета Европы, она ратифицировала европейскую

\footnotetext{
${ }^{6}$ Pravila procedure za rješavanje predmeta bivšeg Doma za ljudska prava Bosne i Hercegovine / Komisije za ljudska prava pri Ustavnom sudu Bosne i Hercegovine, od 1. februara 2007. godine. <http://www. ccbh.ba/bos/p_stream.php?kat=83\&pkat=84>. (Последнее посещение: 25 января 2014 г.).

${ }^{7}$ Амандман I на Устав Босне и Херцеговине, одржаној 26. марта 2009. године. // Official Gazette of Bosne i Hercegovine. No. 25/09. $<$ http://www.ccbh.ba/srp/article.php?pid=1523\&kat=618\&pkat=600>. (Последнее посещение: 25 января 2014 г.).
} 
DOI: $10.7256 / 1811-9018.2014 .2 .10872$

При цитировании этой статьи сноска на доі обязательна

\section{Право и политика $2(170) \cdot 2014$}

Конвенцию о защите прав и основных свобод 1950 г. (далее - Конвенция) и протоколы к ней без каких-либо оговорок, а граждане этого государства получили возможность обращаться в Европейский суд по правам человека (ЕСПЧ) за защитой прав и свобод, гарантированных Конвенцией. Обращаясь к статистическим данным, отметим, что из 47 государств, являющихся членами Совета Европы, БиГ в 2012 г. заняла 16 место (показатель 1,12) по соотношению количества обращений в ЕСПЧ (430) к количеству ее населения (3 829 тыс. чел.), если условиться, что первое место отдано государству, против которого подано больше всего жалоб. Для сравнения укажем, что наиболее высокие показатели имеют Лихтенштейн $(4,44)$ и Греция $(4,35)$, а наиболее низкие - Ирландия $(0,12)$ и Испания $(0,15)$, а средний показатель равен $0,79^{8}$.

Взаимоотношения ЕСПЧ и национальных конституционных судов в государствах-членах Совета Европы подчас являются довольно непростыми и могут иметь свою специфику применительно к отдельным странам и текущей политической ситуации внутри государства и в мире. Но в целом, как замечает бывший Председатель ЕСПЧ Ж.-П. Коста, в отношениях между ЕСПЧ и конституционными судебными органами возможны следующие ситуации: 1) ЕСПЧ может не согласиться с национальным конституционным судом, одобрившим внутреннюю процедуру; 2) ЕСПЧ может занять ту же позицию, что и национальный конституционный суд, и счесть, что конституция соблюдена; 3) национальный конституционный суд и ЕСПЧ приходят к одинаковым выводам - первый о противоречии Конституции, второй - о нарушении Конвенции'.

Если же говорить о БиГ, нам очевидно, что следует выделить еще, по крайней мере, две из возможных ситуаций: 1) Конституционный суд БиГ и ЕСЧП приходят к одинаковым выводам о нарушении Конвенции; 2) ЕСПЧ принимает решение о нарушении Конвенции, а Конституционный суд - о нарушении какого-либо иного международного акта, в котором содержится

\footnotetext{
${ }^{8}$ Выводы сделаны на основе статистических данных об обращениях в ЕСПЧ, приведенных в ежегодном Статистическом анализе ЕСПЧ за 2012 г. // European Court Of Human Rights. Analysis Of Statistics 2012. January 2013. P. 11. <http://echr.coe.int/Documents/ Stats_analysis_2012_ENG.pdf $>$. (Последнее посещение: 25 января 2014 г.).

${ }^{9}$ См.: Коста Ж.-П. Европейский Суд по правам человека: диалог с национальными судами состоялся. // Конституционный контроль: доктрина и практика: материалы международной конференции, посвященной 20-летию Конституционного Суда Российской Федерации (Санкт-Петербург, 28-29 октября 2011 г.) / Под ред. В. Д. Зорькина. М.: Норма, 2012. С. 351.
}

общая норма (например, Международного пакта о гражданских и политических правах 1966 г.). Данный тезис основан на анализе решений Конституционного суда, а также прямо следует из конституционных положений.

Дело в том, что согласно ч. 2 ст. II Конституции права и свободы, закрепленные в Конвенции и в протоколах к ней, имеют прямое действие в БиГ и преимущественную силу относительно всех остальных норм права. Кроме того, мы уже приводили нормы ст. VI Конституции, которыми прямо предусмотрено, что компетенция Конституционного суда включает в себя, в том числе юрисдикцию в отношении вопросов, которые рассматриваются любым судом в БиГ и заключаются в установлении того, не противоречит ли закон, от действительности которого зависит решение суда, Конвенции и протоколам к ней, либо того, что существует ли общая норма международного публичного права, имеющая отношение к решению суда, или какова сфера действия этой нормы. Таким образом, Конституционный суд в БиГ осуществляет не только конституционный, но и так называемый конвенционный контроль (проверка актов на их соответствие Конвенции и протоколам к ней). В то же время представляется, что вынесение Конституционным судом решения по такому делу не исключает юрисдикцию ЕСПЧ по этому же делу.

В связи с этим неизбежно встает вопрос о соотношении юридической силы Конституции БиГ и Конвенции. Сам Конституционный суд неоднократно высказывался по данному вопросу, отмечая следующее: 1) статус Конвенции проистекает из ч. 2 ст. II Конституции, в которой предусмотрено, что права и свободы, закрепленные в Конвенции, реализуются в БиГ непосредственно; 2) упомянутые положения указывают на общий феномен интернационализации внутренней правовой системы в БиГ; 3) обеспечивая соблюдение Конституции, Суд может ссылаться как на текст Конституции, так и Конвенции, что следует из п. «с» ч. 3 ст. VI Конституции; 4) права, гарантированные Конвенцией, не могут иметь преимущественный статус по отношению к Конституции, так как Конвенция как международный документ вступила в силу на территории БиГ на основе Конституции и конституционные полномочия проистекают из Конституции, а не из Конвенции. Одновременно при этом Конституционный суд обращал внимание на отсутствие у него полномочий по оценке Конституции на предмет ее соответствия Конвенции ${ }^{10}$.

\footnotetext{
${ }^{10}$ См., например: Odluka o dopustivosti. Broj: U-5/04. Datum: 27.01.2006. /Službeni glasnik Bosne i Hercegovine 49/06; Odluka o dopustivosti. Broj: U-13/05. Datum: 26.05.2006. /Službeni glasnik
} 
Это лишь одна из особенностей взаимоотношений Конституционного суда БиГ и ЕСПЧ. Пожалуй, более серьезное и прямое влияние последний оказывает при формировании состава национального суда. Так, 4 из 9 членов Конституционного суда избираются Палатой представителей Федерации Боснии и Герцеговины (парламент данного энтитета), 2 члена избираются Скупщиной Республики Сербской (парламент этого энтитета). 3 члена назначаются Председателем ЕСПЧ, после проведения консультаций с Президиумом, причем такие судьи не могут быть гражданами БиГ или какого-либо соседнего государства. Например, назначенный в 2002 г. конституционным судьей Тудор Панцыру является гражданином Румынии, а Констанция Греве, ставшая судьей в 2004 г., - гражданкой ФРГ. Маргарита Тсатса-Николовская, назначенная судьей в 2011 г., имеет гражданство Македонии.

В п. «d» ч. 1 ст. VI Конституции указано, что по истечении 5 лет с момента формирования первого состава Конституционного суда Парламентская скупщина (двухпалатный парламент в БиГ) может принять закон, предусматривающий иной метод отбора трех судей, ныне назначаемых Председателем ЕСПЧ. В настоящее время соответствующий закон не принят, но приведенная выше формулировка не исключает вмешательства во внутренние дела государства, а позволяет парламенту лишь изменить порядок, то есть назначение судей Председателем ЕСПЧ может осуществляться после проведения консультаций не с Президиумом, а, например, с парламентом, либо вообще без каких-либо консультаций.

Таким образом, третью часть состава Конституционного суда БиГ назначает представитель наднационального органа. С одной стороны, такой порядок, видимо, должен сдерживать возможные конфликты и ориентированность Суда на интересы какого-либо одного из государствообразующих народов. Но с другой стороны, подобное положение вещей позволяет нам говорить об ограничении суверенитета государства БиГ и создает почву для рассуждений о том, что национальные судьи при отправлении правосудия более ответственны за судьбу принимаемого решения и глубже понимают национальные особенности государства, нежели судьи-иностранцы.

Для сведения отметим, что формирование органа конституционного контроля с учетом национальных особенностей осуществляется, например, в Швейцарии

Bosne i Hercegovine broj 24/07; <http://www.ccbh.ba/bos/odluke/ index.php?src=2\#>. (Последнее посещение: 25 января 2014 г.). (судьи должны представлять три языка Конфедерации - немецкий, французский, итальянский), в Бельгии (из 12 судей 6 должны представлять франкоязычную часть населения, 6 - нидерландскоязычную), но там в формировании судов не участвуют наднациональные структуры, да и представительство не народов, а языков.

Сам же ЕСПЧ однажды высказывался по вопросу об участии иностранных судей в отправлении правосудия национальными органами, рассматривая дело «Дамьянович и Мактуф против Боснии и Герцеговины», суть которого сводится к следующему.

Заявители, один из которых является гражданином БиГ, а другой - Ирака, были осуждены за совершенные ими во время войны в 1992-1995 гг. военные преступления: избиение и пытки захваченных боснийцев в Сараево в 1992 г., пособничество в захвате заложников в Травнике в 1993 г. Обжалуя судебные приговоры в Конституционный суд, а затем и в ЕСПЧ, осужденные указывали, что при рассмотрении их дел Судом БиГ (Государственным судом) необоснованно применены нормы Уголовного кодекса БиГ 2003 г., хотя положения Уголовного кодекса СФРЮ 1976 г. предусматривали более мягкое наказание за совершенные ими преступления (то есть более строгие нормы применены ретроспективно, а правило об обратной силе норм, устанавливающих более мягкое уголовное наказание, не соблюдено). Одновременно один из заявителей утверждал, что осудивший их суд не был независимым, так как в его состав входили международные судьи, не являющиеся гражданами БиГ, и, следовательно, подверженные влиянию международных органов и организаций и далекие от реальностей политической и общественной жизни в этом государстве.

Как известно, для наказания лиц, виновных в совершении военных преступлений на территории бывшей Югославии в течение нескольких лет, следующих после ее распада, Советом Безопасности ООН в качестве временного института был учрежден Международный трибунал по бывшей Югославии (МТБЮ). В 2002 г. в ходе завершения миссии МТБЮ Советом Безопасности $\mathrm{OOH}(\mathrm{CБ} \mathrm{OOH})$ и властями БиГ было утверждено соглашение, в соответствии с которым в рамках высшего национального суда (Суд БиГ или Государственный суд) были созданы отделения по рассмотрению военных преступлений. В состав последних назначаются преимущественно иностранные судьи, не являющиеся ни гражданами БиГ, ни соседних с ней государств. Международные судьи назначаются главой международной администрации в БиГ - Высоким представителем. Эта должность была введена с одобрения СБ 
DOI: $10.7256 / 1811-9018.2014 .2 .10872$

При цитировании этой статьи сноска на доі обязательна

\section{Право и политика 2 (170) 2014}

ООН Советом по выполнению мирного соглашения (неофициальное объединение государств по мирному урегулированию) в качестве принудительной меры (между прочим заметим, что полномочия Высокого представителя чрезмерно широкие и позволяли ему неоднократно принимать обычные законы, вносить поправки в конституции энтитетов, увольнять лиц с некоторых государственных должностей, а его вмешательство во внутренние дела государства и заявления международной общественности о постоянной неспособности политиков принять отдельные решения и вывести страну из «застоя» вызывают новые волны политического кризиса и общественной нестабильности, а также усугубляют напряженность в стране).

ЕСПЧ в своем решении ${ }^{11}$ указал, что: 1) подобное назначение создает предпосылки и механизмы, которые укрепляют независимость судей от вмешательства и влияния со стороны исполнительной власти или международных органов, а также направлено на обеспечение независимости и беспристрастности судебной системы и отправления правосудия; 2) международные судьи обязаны уважать и применять те правила, которые обычно применяются в национальном уголовном праве и соответствуют международным стандартам; 3) смысл назначения международных судей состоит в необходимости создания и укрепления национальных судов в переходный период и поддержке их усилий в установлении ответственности за серьезные нарушения прав человека и этнически мотивированные преступления. На основании приведенных доводов, которые нам представляются отнюдь не бесспорными, ЕСПЧ согласился с позицией Конституционного суда и посчитал, что заявитель не смог доказать отсутствие независимости и беспристрастности международных судей, участвующих в отправлении правосудия в национальном суде.

Влияние ЕСПЧ на Конституционный суд БиГ не ограничивается только назначением третьей части состава последнего, а также своими прецедентами, на которые Суд ссылается при рассмотрении дел о нарушениях прав и свобод человека. Практика показывает, что ЕСПЧ влияет и на процедуры рассмотрения дел в Конституционном суде, причем не только косвенно, через назначенных Председателем ЕСПЧ членов Суда,

\footnotetext{
${ }^{11}$ Judgment. Case Of Maktouf And Damjanović V. Bosnia And Herzegovina (Applications Nos. 2312/08 And 34179/08). Strasbourg. 18 July 2013. <http://www.sudbih.gov.ba/files/docs/CASE_OF_MAKTOUF_ AND_DAMJANOVIC_v_BOSNIA_AND_HERZ̄EGOVINA_JDG. pdf $>$. (Последнее посещение: 25 января 2014 г.).
}

которые наряду с остальными судьями утверждают Правила его работы, но и непосредственно. Примером подобного случая является дело «Авдич и другие против Боснии и Герцеговины», постановление по которому ЕСПЧ вынес в конце ноября 2013 г. Суть упомянутого дела сводится к следующему.

В ЕСПЧ обратились трое граждан БиГ с жалобами на действия Конституционного суда, в результате которых им было, по сути, отказано в доступе к суду. Заявители обращались в Конституционный суд в индивидуальном порядке, обжалуя постановления Государственного суда по их трудовым спорам. В период рассмотрения этих жалоб Конституционный суд действовал не в полном составе (в двух случаях были назначены лишь 8 судей из 9, а в одном - 7). Исходя из положений п. 2 ст. 40 Правил, на пленарном заседании Конституционный суд принимает решения большинством голосов судей от общего количества членов, установленного для его состава - 9 судей. Таким образом, для принятия какого-либо решения по запросу или апелляции в неполном составе Суда необходимо было достижение единогласия по проекту решения не менее 5 судьями (как и при полном составе). На практике это удавалось далеко не всегда, что приводило к невозможности принятия решения, затягиванию конституционного производства, увеличению количества возбужденных, но не завершенных процессов.

Видимо, с тем, чтобы обеспечить возможность принятия Конституционным судом решений в тех случаях, когда он не сформирован в полном составе, в 2009 г. ст. 40 Правил была дополнена п. 3 следующего содержания: «В исключительных случаях, когда в процедуре принятия решения на пленарном заседании Суда участвуют менее 9 судей, по причинам, упомянутым в п. 1 ст. 93 (увольнение с должности судьи) или п. 6 ст. 99 (временное отстранение от занимаемой должности до окончания уголовного производства в отношении судьи) Правил, а также в случае, если назначены еще не все судьи либо в связи с неспособностью одного из судей осуществлять свои функции по причине длительной болезни, если, как минимум 5 судей не проголосовали одинаково по проекту решения по запросу/апелляции, считается, что принято решение, которым запрос/апелляция отклонены».

Именно на основании п. 3 ст. 40 Правил было отказано заявителям, то есть Конституционный суд отклонил их жалобы по формальным основаниям, не разрешив по существу. Соответствующие решения Суда являются обязательными и окончательными. 
Заявители утверждали, что: 1) ограничения их права на доступ к суду на основе применения п. 3 ст. 40 Правил были несоразмерными; 2) Конституционный суд фактически отказал им в возможности рассмотрения судом их дел и принятия решений по существу; 3) Суд необоснованно переложил на заявителей проблемы, связанные с неукомплектованностью Суда и его загрузкой апелляциями; 4) Суд не обеспечил равный доступ для всех заявителей, поскольку жалобы одних будут рассмотрены по существу на пленарном заседании в составе 9 судей, а жалобы других будут автоматически отклонены, по формальным основаниям.

Правительство БиГ утверждало в ЕСПЧ, что все заявители воспользовались своим правом на обращение в суд, апеллируя в Конституционный суд, который вынес окончательное решение по установленной им процедуре. Ограничение доступа к суду, предусмотренное в п. 3 ст. 40 Правил, по мнению Правительства, является соразмерным и служит законной цели: обеспечение быстрого разрешения постоянно увеличивающихся в количестве дел и нормального функционирования Суда, без задержек, в случае отсутствия кого-либо из судей.

ЕСПЧ, частично удовлетворяя упомянутые жалобы, указал ${ }^{12}$, что: 1) Конвенция гарантирует каждому право на разрешение любого спора о его гражданских правах и обязанностях в суде; 2) она обеспечивает «право на суд», из которого проистекает право на доступ к суду, в том числе право инициировать производство в судах; 3) конечно, «право на суд» не является абсолютным, государство пользуется определенной свободой усмотрения во введении ограничений, определяющих условия допустимости апелляции; 4) но такие ограничения не должны сужать доступ к суду до такой степени, при которой нарушается сама суть права; 5) подобные ограничения не будут совместимы с Конвенцией, если они не преследуют законную цель либо нет разумной соразмерности между используемыми средствами и целью, которая в итоге должна быть достигнута. ЕСПЧ посчитал, что Правительство не смогло доказать разумную соразмерность ограничений доступа к суду, а также не представило сведения о том, что имели место попытки найти альтернативные решения проблем, связанных с функционированием Конституционного суда. В рассматриваемых случаях, несмотря на то,

12 Judgment. Case Of Avdić And Others V. Bosnia And Herzegovina (Applications Nos. 28357/11, 31549/11 And 39295/11). Strasbourg. 19 November 2013. <http://hudoc.echr.coe.int/sites/eng/Pages/search. aspx\#\{“"sort”:[“kpdate\%20Descending"],"respondent":[“BIH”],"doc umentcollectionid2":[“JUDGMENTS"],"itemid":[“001-128202"]\}>. (Последнее посещение: 27 января 2014 г.). что решения Конституционного суда являются окончательными, они не включают в себя окончательную «определенность» гражданских прав и обязанностей заявителей. В то время как Конституционный суд принял формальное решение по апелляциям заявителей, он в действительности отказался решать вопросы об их приемлемости и/или оценке по существу. Единственная причина, по которой Конституционный суд отклонил жалобы заявителей, это не достижение согласия большинством судей по любому из вопросов, которые должны определить гражданские права и обязанности заявителей. Другими словами, не было достигнуто большинства голосов судей ни для удовлетворения, ни для отклонения апелляции. Как подчеркнул ЕСПЧ, когда не существует реальной «определенности» гражданских прав и обязанностей, право на доступ к суду становится иллюзорным.

Доводы ЕСПЧ, на наш взгляд, являются разумными и обоснованными, но не исключено, что подобная ситуация могла быть спровоцирована, в том числе пробелами в Конституции БиГ. Ведь в ее ч. 2 ст. VI, посвященной процедурам Суда, требование о количестве голосов, необходимом для принятия решения (большинство всех его членов), установлено лишь применительно к порядку утверждения Правил, но не решений по предмету юрисдикции Суда.

Еще одним проблемным вопросом для БиГ, впрочем как и для ряда других государств, является исполнение решений ЕСПЧ. Причем это государство, возможно, более интенсивно, чем другие, подвергается в связи с этим давлению иностранных государств, их объединений, а также международных и наднациональных органов и организаций. Так, к примеру, в декабре 2013 г. под предлогом понуждения к исполнению решения ЕСПЧ путем проведения конституционной реформы к стране были применены серьезные финансовые санкции со стороны ЕС и Европейской комиссии. Речь идет о деле «Сейдич и Финци против Боснии и Герцеговины», суть которого заключается в следующем.

Оба заявителя являются гражданами БиГ, но один из них имеет цыганское, а другой - еврейское происхождение. Согласно Конституции кандидатами на должности в Президиум и в верхнюю палату парламента - Палату народов могут быть только представители государствообразующих народов (сербы, хорваты, боснийцы). Таким образом, Сейдич и Финци, принадлежащие к национальным меньшинствам, проживающим в БиГ, ограничены в пассивном избирательном праве по этническому признаку. По мнению заявителей, соответствующие положения Конституции нарушают 
DOI: $10.7256 / 1811-9018.2014 .2 .10872$

При цитировании этой статьи сноска на доі обязательна

\section{Право и политика $2(170) \cdot 2014$}

Конвенцию, поскольку допускают необоснованную дискриминацию по этническому происхождению. Конституционный суд БиГ отказал в удовлетворении жалоб заявителей, в связи с чем они обратились в ЕСПЧ.

ЕСПЧ в решении ${ }^{13}$ по данному делу указал, что: 1) дискриминация, основанная исключительно на национальности лица, не может быть объективно оправданной в современном демократическом обществе; 2) исключение, предусмотренное изначально в Конституции, преследовало цель, в широком смысле совместимую с общими задачами Конвенции, а именно с задачей восстановления мира, поскольку оно должно было положить конец жестокому конфликту, отмеченному геноцидом и «этнической чисткой»; 3) характер конфликта был таков, что установление «основных национальностей» было необходимо для поддержания мира, и это могло объяснить отсутствие представителей других сообществ-таких, как местные цыганские и еврейские сообщества - на мирных переговорах и озабоченность их участников эффективным равенством между «основными национальностями» в обществе после конфликта. ЕСПЧ отметил, что в БиГ наблюдается существенное позитивное развитие после Дейтонского мирного соглашения: в 2005 г. бывшие стороны конфликта отказались от контроля за вооруженными силами и реформировали их в небольшую профессиональную армию; в 2006 г. БиГ присоединилась к программе НАТО «Партнерство во имя мира»; в 2008 г. страна подписала и ратифицировала Соглашение о стабилизации и ассоциации с ЕС; в марте 2009 г. она успешно изменила государственную Конституцию в первый раз; и недавно она была избрана членом СБ ООН. В связи с этим ЕСПЧ посчитал, что БиГ достигла того уровня развития, когда оспариваемые конституционные положения уже представляются нарушающими общий запрет на дискриминацию, установленный в Конвенции, и необоснованно лишают заявителей возможности выставлять свою кандидатуру на выборах в Президиум и в Палату народов.

Упомянутое решение было вынесено в 2009 г., но власти БиГ до сих пор не смогли договориться о внесении соответствующих изменений в Конституцию, хотя вопрос об этом неоднократно поднимался, но вызывал внутриполитические разногласия. В ноябре

\footnotetext{
${ }^{13}$ Judgment. Case Of Sejdić And Finci V. Bosnia And Herzegovina (Applications Nos. 27996/06 And 34836/06). Strasbourg. 22 December 2009. <http://hudoc.echr.coe.int/sites/eng/Pages/search.aspx\# ‘ "langu ageisocode":["ENG”],"appno":[“27996/06","34836/06"],"documen tcollectionid2”:[“GRANDCHAMBER"],"itemid":[“001-96491”]\}>. (Последнее посещение: 27 января 2014 г.).
}

2013 г. Высокий представитель, австрийский дипломат В. Инцко, выступая с ежегодным полугодовым докладом в СБ ООН, подверг критике власти БиГ, отметив, что неспособность политических лидеров решить вопрос о военном имуществе и скорректировать Конституцию в соответствии с требованиями ЕСПЧ, следующих из решения по делу «Сейдич-Финци», заблокировала стране путь в ЕС и в НАТО. При этом, говоря о проблеме выполнения решения ЕСПЧ, В. Инцко подчеркнул, что конституционные изменения - это не только условие для дальнейшего продвижения страны к членству в ЕС, но и проверка способности БиГ применять основные стандарты прав человека ${ }^{14}$. А в конце декабря 2013 г. Европейская комиссия приняла решение сократить финансовую поддержку БиГ в рамках программы подготовки к вступлению в ЕС на 45 млн. евро (теперь стране доступны только 41,9 млн. евро), мотивируя его своим недовольством неспособностью политиков договориться об исполнении судебного вердикта по названному делу ${ }^{15}$. Здесь же заметим, что в связи с упомянутыми обстоятельствами прокуратура БиГ начала расследование по факту невыполнения решения ЕСПЧ.

В свою очередь напомним, что до принятия Дейтонских соглашений в БиГ на основе Конституции Социалистической Республики Боснии и Герцеговины 1974 г. был установлен принцип формирования Президиума на основе национальной (этнической) принадлежности, при этом обязательным было представительство не только боснийцев, хорватов и сербов, но и других народов, проживающих на территории Республики. Так, первоначально, в состав Президиума избирались 9 членов, а после первых многопартийных выборов в декабре 1990 г. в него входили 7 членов: по два члена от боснийского, сербского и хорватского народов и один представитель от остальных народностей. Существующий в настоящее время порядок формирования Президиума и Палаты народов предусмотрен Конституцией, навязанной другими государствами в 1995 г. А ЕСПЧ полагает, что вправе решать, пришло ли время считать принципы, заложенные в навязанной БиГ Конституции, недемократическими, или нет.

Таким образом, учитывая приведенные нами в настоящей статье доводы и примеры дел, мы можем

\footnotetext{
${ }^{14}$ Международный администратор раскритиковал боснийских лидеров в СБ ООН. <http://ria.ru/world/20131113/976431579.html>. (Последнее посещение: 27 января 2014 г.).

${ }^{15}$ ЕК снизила финансовую поддержку Боснии и Герцеговины. $<$ http://ria.ru/world/20131223/985993041.html>. (Последнее посещение: 27 января 2014 г.).
} 
заключить, что фактически для ЕСПЧ не существует пределов для вмешательства в деятельность Конституционного суда БиГ. А последний представляется более независимым от национальных органов, чем от ЕСПЧ.

Активное вмешательство во внутреннюю жизнь БиГ иностранных государств, международных и наднациональных органов и организаций, сохраняющееся несмотря на прекращение военных действий на территории государства почти 20 лет назад, мотивируется недостаточным уровнем развития демократических институтов в БиГ, а по сути, недовольством поведением ее политических лидеров. Однако подобное вмешательство во внутренние дела государства отнюдь не способствует привитию самостоятельности и пробуждению ответственности за создаваемую государственность у его политических деятелей, да и у рядовых граждан. Наоборот, такие односторонние действия, в том числе по навязыванию новой конституционной реформы или, допустим, союзничества либо ассоциации с другими странами, а особенно, если они подкреплены финансовыми рычагами воздействия, могут только дестабилизировать политическую ситуацию и обострить напряженность в стране, создать предпосылки для попыток насильственного свержения конституционного строя и кровопролития, примеров чего немало как в мировой истории, так и в текущий момент времени.

\section{Библиография:}

1. Абашидзе А. Х., Солнцев А. М. Балканы - ахиллесова пята евро-атлантической безопасности. К 15-летию Дейтонских соглашений. // ОбозревательObserver. 2010. № 8. С. 57-65.

2. Зорькин В.Д. Конституционный контроль: доктрина и практика: материалы международной конференции, посвященной 20-летию Конституционного Суда Российской Федерации (Санкт-Петербург, 28-29 октября 2011 г.) / Под ред. В.Д. Зорькина. М., 2012.-464 c.

3. Маклаков В.В. Конституционный контроль в зарубежных странах: учеб. пособие / отв. ред. В. В. Маклаков. - 2-е изд., испр. и доп. М., 2010.-672 с.

4. Гуськов Е.Ю. Международный трибунал по бывшей Югославии: Деятельность, результаты, эффективность. Материалы Международной научной конференции (Москва, 22 - 23 апреля 2009 г.) / Отв. ред. Е. Ю. Гуськова. М., 2012.-544 с.

5. Месич С. Как развалилась Югославия. М., 2013.-394 с.
6. Мильчакова О. В. Конституционная юстиция в Хорватии: становление, развитие, основы организации. Монография. М., 2013.-174 с.

7. Мильчакова О. В. Конституционный контроль в странах бывшей Югославии. М., 2014.-308 с.

8. Кузманович Р. Трактаты о конституционно-правовом положении Республики Сербской: монография. М., 2013.-463 c.

9. Пономарева Е. Г. Новые государства на Балканах: Монография. М., 2010.-252 с.

10. Султанов А. Р. Европейские правовые стандарты, уроки истории и правоприменительная практика. М., 2012.-335 с.

11. Иодковский Э.В. Соотношение юрисдикций Конституционного Суда Российской Федерации и Европейского Суда по правам человека и их влияние на гражданское судопроизводство // Актуальные проблемы российского права. - 2012. - 1. - С. 196-205.

12. Г. Г. Шинкарецкая Европейский союз и Европейская конвенция о защите прав человека и основных свобод // Международное право и международные организации / International Law and International Organizations.-2012.-1.-C. 54-64.

13. Аверьянов К.Ю. Решения Европейского суда по правам человека в системе источников права // Актуальные проблемы российского права.-2012.2.-C. 275-284.

14. Султанов А.Р. Правовые последствия Постановлений Европейского Суда по правам человека в гражданском процессе//Международное право и международные организации/International law and international organizations, - 2010. - № 3 .

15. Кузьмина Ю.А. Некоторые особенности практики Европейского Суда в отношении Российской Федерации // NB: Международное право. - 2013. - 3. - C. 68 - 87. URL: http://www.e-notabene.ru/wl/ article_2424.html

\section{References (transliteration):}

1. Abashidze A. Kh., Solntsev A. M. Balkany-akhillesova pyata evro-atlanticheskoi bezopasnosti. K 15-letiyu Deitonskikh soglashenii. // Obozrevatel'-Observer. 2010. № 8. S. 57-65.

2. Zor'kin V.D. Konstitutsionnyi kontrol': doktrina i praktika: materialy mezhdunarodnoi konferentsii, posvyashchennoi 20-letiyu Konstitutsionnogo Suda Rossiiskoi Federatsii (Sankt-Peterburg, 28-29 oktyabrya 2011 g.) / Pod red. V.D. Zor'kina. M., 2012.-464 s. 
DOI: $10.7256 / 1811-9018.2014 .2 .10872$

При цитировании этой статьи сноска на доі обязательна

\section{Право и политика $2(170) \cdot 2014$}

3. Maklakov V.V. Konstitutsionnyi kontrol' v zarubezhnykh stranakh: ucheb. posobie / otv. red. V. V. Maklakov. - 2-e izd., ispr. i dop. M., 2010.-672 s.

4. Gus'kov E.Yu. Mezhdunarodnyi tribunal po byvshei Yugoslavii: Deyatel'nost', rezul'taty, effektivnost'. Materialy Mezhdunarodnoi nauchnoi konferentsii (Moskva, 22 - 23 aprelya 2009 g.) / Otv. red. E. Yu. Gus'kova. M., 2012.-544 s.

5. Mesich S. Kak razvalilas' Yugoslaviya. M., 2013.-394 s.

6. Mil'chakova O. V. Konstitutsionnaya yustitsiya v Khorvatii: stanovlenie, razvitie, osnovy organizatsii. Monografiya. M., 2013.-174 s.

7. Mil'chakova O. V. Konstitutsionnyi kontrol' v stranakh byvshei Yugoslavii. M., 2014.-308 s.

8. Kuzmanovich R. Traktaty o konstitutsionno-pravovom polozhenii Respubliki Serbskoi: monografiya. M., 2013.-463 s.

9. Ponomareva E. G. Novye gosudarstva na Balkanakh: Monografiya. M., 2010.-252 s.

10. Sultanov A. R. Evropeiskie pravovye standarty, uroki istorii i pravoprimenitel'naya praktika. M., 2012.-335 s.

11. Iodkovskii E.V. Sootnoshenie yurisdiktsii Konstitutsionnogo Suda Rossiiskoi Federatsii i Evropeiskogo
Suda po pravam cheloveka i ikh vliyanie na grazhdanskoe sudoproizvodstvo // Aktual'nye problemy rossiiskogo prava. - 2012. - 1. - C. 196-205.

12. G. G. Shinkaretskaya Evropeiskii soyuz i Evropeiskaya konventsiya o zashchite prav cheloveka i osnovnykh svobod // Mezhdunarodnoe pravo i mezhdunarodnye organizatsii / International Law and International Organizations. - 2012. 1. - C. 54-64.

13. Aver'yanov K.Yu. Resheniya Evropeiskogo suda po pravam cheloveka $\mathrm{v}$ sisteme istochnikov prava // Aktual'nye problemy rossiiskogo prava. - 2012. - 2. - C. 275-284.

14. Sultanov A.R. Pravovye posledstviya Postanovlenii Evropeiskogo Suda po pravam cheloveka v grazhdanskom protsesse//Mezhdunarodnoe pravo i mezhdunarodnye organizatsii/International law and international organizations, - 2010. - № 3.

15. Kuz'mina Yu.A. Nekotorye osobennosti praktiki Evropeiskogo Suda v otnoshenii Rossiiskoi Federatsii // NB: Mezhdunarodnoe pravo. - 2013. - 3. - C. 68 - 87. URL: http://www.e-notabene.ru/ wl/article_2424.html 